\title{
Preterm Bebeği Olan Annelere Yapılan Taburculuk Eğitimi ve Ev Ziyaretlerinin Bebeğin Büyüme -Gelişmesine ve Annelerin Bakım Sorunlarını Çözme Becerileri Üzerine Etkisi*
}

\section{The Effect of Discharge Planning and Home Visits on Growth and Development of the Babies and Problem Solving Skills of Their Mothers}

\author{
Serap BALCI ${ }^{\mathrm{a}}$ Suzan YILDIZ $^{\mathrm{b}}$ iD
}

\begin{abstract}
ÖZET Amaç: Preterm bebeği olan annelere yapılan taburculuk eğitimi ve ev ziyaretlerinin bebeğin büyümegelişmesine ve annelerin bakım sorunlarını çözme becerilerine etkisini belirlemek amacıyla yapılmıştır. Gereç ve Yöntemler: Deneysel ve izlemsel tipteki çalışma, İstanbul'daki 3 hastanenin yenidoğan yoğun bakım ünitelerinde yatan basit rastgele örnekleme yöntemi ile belirlenen 63 anne (deney $=31$; kontrol $=32$ ) ve 75 preterm bebeği (deney=37; kontrol=38) ile gerçekleştirildi. Deney grubu annelere taburculuktan önce preterm bebeğin bakımına yönelik hazırlanan 3 oturum şeklinde bir eğitim programı düzenlendi. Taburculuktan sonra ise hem deney hem de kontrol grubuna toplam $4 \mathrm{kez}$ ev ziyareti yapıldı. Ziyaret sırasında annelere "Sorun Çözme Becerileri Değerlendirme Formu (SÇBDF)" ve bebeklere ise "Ankara Gelişim Tarama Envanteri (AGTE)" uygulandı ve bebeğin antropometrik ölçümleri alınarak kaydedildi. Bulgular: Deney grubundaki bebeklerin AGTE’ten aldıkları genel gelişim puanı kontrol grubuna göre anlamlı düzeyde daha yüksek idi $(\mathrm{p}<0.001)$. SÇBDF'den deney grubu annelerin $184.1 \pm 17.4$ puan, kontrol grubu annelerin $155.2 \pm 22.0$ puan aldığ 1 ve farkın deney grubu lehine ileri düzeyde anlamlı olduğu saptandı $(\mathrm{p}<0.001)$. Ancak her iki gruptaki bebeklerin antropometrik ölçümleri arasında anlamlı bir fark bulunmadı ( $>>0.05$ ). Sonuç: Preterm bebeği olan annelere yapılan taburculuk eğitiminin ve ev ziyaretlerinin bebeklerin gelişimleri ve annelerin sorun çözme becerileri üzerinde etkili olduğu saptandı.
\end{abstract}

Anahtar Kelimeler: Büyüme-gelişme, ev ziyareti, hemşirelik, preterm, taburculuk eğitimi

\begin{abstract}
Aim: It was perfomed to determine the effect of discharge planning and home visits on growth and development of the babies and problem solving skills of their mothers. Material and Method: The experimental type study consisted of 63 mothers (experiment=31;control=32) and 75 preterm babies (experiment=37 ;control=38) determined by simple random sampling method in the Neonatal Intensive Care Units of 3 hospitals in Istanbul. The experimental group had a 3-session training program for mothers of preterm babies before their discharge. After the discharge, a total of 4 visits were made to both the experimental group and the control group. During the visit, to Mothers "Problem Solving Skills Assesment Questionare: How To Deal with Problems Regarding Care of My Baby (SÇBDF)" and to infants "Ankara Developmental Screening Inventory (AGTE)" were applied and their anthropometric measurements were taken and recorded. Results: The general development score received from AGTE of the babies in the experimental group was significantly higher than the control group $(p<0.001)$. It was found that the score received from SCBDF were $184.1 \pm 17.4$ points for the experimental group and $155.2 \pm 22.0$ points for the control group, and the difference was found to be highly significant for the experimental group $(\mathrm{p}<0.001)$. However, there was no significant difference between the anthropometric measurements of the infants in both groups ( $p>0.05)$. Conclusion: Discharge training and home visits to mothers with preterm infants were found to be influential on infant development and mothers' problem-solving skills.
\end{abstract}

Key Words: Growth and development, home visits, nursing, preterm, discharge planning

\section{Giriş}

Dünya Sağlık Örgütüne (DSÖ) göre; preterm yenidoğan, 37. gestasyon haftasindan önce canlı olarak doğan bebeklerdir. Preterm doğum oranı-

nın az gelişmiş ülkelerde ortalama \%12'lerde, gelişmiş ülkelerde ise \%9'larda olduğu belirtilmektedir. ${ }^{1}$

Geliş Tarihi/Received: 28-06-2017 / Kabul Tarihi/Accepted:09-08-2017

${ }^{a}$ :Yard. Doç. Dr. İstanbul Üniversitesi Florence Nightingale Hemşirelik Fakültesi, Çocuk Sağlığı ve Hastalıkları Hemşireliği Anabilim Dalı, ORCID ID: 0000-0001-8915-6690

${ }^{b}$ Prof. Dr. İstanbul Üniversitesi Florence Nightingale Hemşirelik Fakültesi, Çocuk Sağlığı ve Hastalıkları Hemşireliği Anabilim Dalı, ORCID ID: 0000-0002-2528-2185

*İstanbul Üniversitesi Sağlık Bilimleri Enstitüsü Çocuk Sağlığı ve Hastalıkları Hemşireliği Anabilim Dalı Hemşirelik Programı Doktora Tezi

Sorumlu yazar /Correspondence: Serap Balcı, İstanbul Üniversitesi Florence Nightingale Hemşirelik Fakültesi, Çocuk Sağlığı ve Hastalıkları Hemşireliği Anabilim Dalı, e-mail:seraybalci@ hotmail.com 
Preterm bir bebeğin doğumu ailede büyük bir hayal kırıklığı, suçluluk, öfke, stres, anksiyete, depresyon gibi durumlar yaratabilir. Yaşanan bu durumlar annelerin preterm bebekleri ile olan ilişkisinde ve bebek bakımı konusunda güçlük yaşamasına neden olmaktadır. 2-5 Annenin bebeğini kabullenmesi, ona bakabilecek düzeye gelmesi ve kendine güvenmesi çok önemlidir. ${ }^{6,7}$ Özellikle anne ve bebek arasındaki etkileşimin yetersiz olmasının, bebeğin büyüme ve gelişimini olumsuz yönde etkilediği belirtilmektedir. ${ }^{5} \mathrm{Bu}$ nedenle anne, taburcu olmadan önce bebeğinin bakımına aktif olarak katılmalı, gereksinimi olduğu konularda eğitilmeli, ${ }^{8,9}$ taburculuk sonras1 yapılacak izlemler ile desteklenmeli ve yalnız birakılmamalıdır. ${ }^{10}$

Preterm bebeği olan ebeveynlerin önemli gereksinimlerinden birinin bebeğin evdeki bakımına yönelik bilgilenme $e^{5,10-12}$ ve beceri kazanması olduğu belirtilmektedir. ${ }^{4}$ Ebeveynlere evdeki bakıma yönelik yapılacak olan eğitim, bebeğin yenidoğan ünitesine girdiği andan itibaren başlamalıdır., ${ }^{2,8}$ Yapılan eğitimin, bebeğin sağllğının sürdürülmesinde, ebeveynlerin bilgi, beceri ve özgüvenlerinin arttırılmasında ve eve geçişin yarattı̆̆ anksiyete ve stresin en aza indirilmesinde etkili olduğu, ${ }^{2,3}$ dolayısıyla bebeğin tekrar hastaneye yatışını, hastalık veya ölüm risklerini azalttığı belirtilmektedir. ${ }^{4}$ Preterm bir bebeğin doğumunun yanında taburcu edilmesi de ebeveynler arasinda yoğun bir strese neden olmaktadır. ${ }^{4,9,10,13}$ Çünkü taburculuk ile birlikte bebeğin tüm sorumluluğunu alma zamanı gelir, ${ }^{9}$ ailede mutluluk, sevinç ve anksiyete duyguları birbirine karışabilir. ${ }^{14} \mathrm{Bu}$ nedenle eve geçiş döneminde; ebeveynlerin evdeki bakıma hazırlanmasi, uzun süreli izlenmesi ve taburculuktan sonra evde bakım hizmetlerinin verilmesi ile yenidoğan ve ailesinin sağllğı korunabilir ve geliştirilebilir. ${ }^{10}$

Araştırma, preterm bebeği olan ailelere yönelik taburculuktan önce verilen planlı taburculuk eğitiminin ve yapılan ev ziyaretlerinin annenin sorun çözme becerisi ve preterm bebeğin büyüme-gelişmesi üzerine etkisini belirlemek amacıyla gerçekleştirilmiştir.

\section{Gerec ve Yöntemler}

Deneysel ve izlemsel tipteki araştırma, İstanbul'daki 3 hastanenin (2 üniversite, 1 devlet) Yenidoğan yoğun bakım ünitelerinde yatan ve seçim kriterlerine uyan preterm bebekler ve anneleri ile gerçekleştirildi. Araştırma grubunda örneklem sayısının belirlenmesi için yapılan power analizi sonucunda; Bebeğimin Bakım Sorunlart İle Ilgilenme Durumum (SÇBDF) ve Ankara Gelişim Tarama Envanteri'nin (AGTE) genel gelişim parametreleri için Delta $=2,5$; $\mathrm{SD}=3,4$ olarak alındığında $\beta=0,20$ ve $\alpha=0,05$ için tespit edilen örneklem sayısı her bir grup için 30'ar bebek ve annesi olarak belirlendi.

Araştırmanın yapılacağ 1 ünitelerde yatan, seçim kriterlerine uyan ve çalışmaya katılmayı kabul eden 86 anne ve 86 preterm bebeği örnekleme alındı. Bebeklerin bazılarının ikiz olması nedeniyle diğer ikiz eşleri de seçim kriterlerine uygunsa örnekleme dahil edildi. Böylece araştırmaya 86 anne ve 98 preterm bebeği alındı. Grupların oluşturulmasında basit rastgele örnekleme yöntemi kullanıldı. Ancak araştırma süresince, çeşitli nedenlerle hem kontrol hem de deney grubundan vaka kayıları oldu. Böylece araştırma, toplam 63 anne (deney $=31$, kontrol $=32$ ) ve ikiz eşleri de dahil edildiği için 75 preterm bebek (deney $=37$, kontrol=38) ile gerçekleştirildi.

\section{Araştırmanın Hipotezleri}

Hipotez 1: Preterm bebeği olan annelere yapilan taburculuk eğitimi ve ev ziyaretleri bebeğin fiziksel büyümesini arttırır.

Hipotez 2: Preterm bebeği olan annelere yapılan taburculuk eğitimi ve ev ziyaretleri bebeğin mental-motor gelişimini arttırır.

Hipotez 3: Preterm bebeği olan annelere yapilan taburculuk eğitimi ve ev ziyaretleri annelerin sorun çözme becerilerini geliştirir.

\section{Araştırmanın Değişkenleri:}

Bağımsız değişkenler; taburculuk eğitimi, düzeltilmiş yaşa göre 9 ay boyunca yapılan ev ziyaretleri,

Bağımlı değişkenler ise preterm bebeğin vücut ağırlığı, boy uzunluğu ve baş çevresi ölçümleri, SÇBDF ve AGTE'den aldıkları puanlardır.

\section{Araştırma Grubu Seçim Kriterleri}

Bebeğin 28-36 gestasyon haftaları arasında olmas1 (28 haftadan küçük pretermler, hastanede kalış süreci ve tıbbi sorunları daha fazla olduğu için alınmad1), gestasyon yaşına uygun tartıda olmas1, konjenital anomalisinin bulunmamas1, ağır nörolojik sorunlarının (intrakraniyal kanama, ciddi perinatal asfiksi vb) olmamas1.

Annenin daha önce preterm bebek bakımı konusunda eğitim almamış olması, araştırmaya katılmaya gönüllü olmasıdır. 


\section{Veri Toplama Araçları}

Bebeğimin Bakım Sorunlart Ile Ilgilenme Durumum (SÇBDF); 1982 yılında Pridham ve Chang tarafından geliştirilmiş, Yazıcı (1995) tarafindan Türkçe geçerlik ve güvenirlik çalışması yapılmıştır. Form 8 alt ölçekten oluşmaktadır. Tüm ölçeğin toplam madde sayısı 29'dur. Her bir maddeye 1'den 9'a kadar değişen puan verilmektedir. Ölçekten alınan en düşük puan 24 , en yüksek puan $216^{\prime}$ dır. Puan arttıkça annelerin sorun çözme becerileri artmaktadır. Form normal yeni doğanlarda doğumdan 1 ay sonra ${ }^{6}$ preterm yeni doğanlarda ise düzeltilmiş yaşa göre 1. ayda uygulanmaktadır. Formu yanıtlama süresi yaklaşık 10-15 dakikadır.

Ankara Gelişim Tarama Envanteri (AGTE); 06 yaş bebek ve çocukların şu andaki dil bilişsel, ince motor, kaba motor, sosyal beceri-öz bakım ve genel gelişimi ile ilgili derinlemesine ve sistemli bilgi sağlayan bir tarama aracıdır. Savaşır, Sezgin ve Erol (1998) tarafindan geliştirilmiştir. Envanterin, gelişimsel gecikme açısından risk altında olduğu düşünülen bebek ve çocukların erken dönemde tanınmasını sağladığı bildirilmektedir. Envanterin; Dil Bilişsel (DB), İnce Motor (IM), Kaba Motor (KM), Sosyal Beceri-Öz bakım (SB-ÖB) olmak üzere toplam 4 alt boyutu vardır. Türk kültürüne özgü olarak geliştirilen AGTE toplam 154 maddeden oluşmaktadır. Gelişim puanlarını yorumlamada "T Puan (Toplam Puan) Tablosu ve Genel Gelişim ve Alt Test Ham Puanları Profili" formları kullanılmaktadır. Çocuğun ham puanına denk gelen T puanı, 40'1n üstünde ise çocuğun gelişiminin yaşına uygun olduğu, $\mathrm{T}$ puanı 35 ve altında ise gelişiminin yaş düzeyinden geri olabileceği ifade edilmektedir. $\mathrm{T}$ puanı yükseldikçe mental-motor gelişiminin daha iyi olduğundan söz edilebilir. ${ }^{15}$

Preterm Bebeğin İzlem Formu; bebeğin fiziksel ölçümlerinin (vücut ağırlığı, boy uzunluğu, baş çevresi), danışmanlık yapılan konuların ve bebeğe ait bilgilerin belirli aralıklarla kaydedildiği bir formdur.

\section{Fiziksel Ölçümleri Almak İçin Kullantlan}

Araçlar; Araştırmacı tarafindan sağlanan, Soehnle 8310 markalı Dijital hassas tartı, baş kısmı sabit ve ayak kısmı oynar olan tahta boy ölçme aleti ve esnemeyen mezüre kullanılmıştır.

\section{Uygulama}

Vaka seçim kriterlerine uyan ve hastanede yatan preterm bebeklerin anneleri ile tanışılarak, araştırma hakkında görüşüldü. Annelere hastaneden çıkış sonrası izleme sürecini kabul edip etmedikleri soruldu. Kabul eden annelerle Görüşme formu dolduruldu. Deney grubundaki annelere, taburcu olmadan önce yapilmas1 planlanan eğitim programı hakkında bilgi verildi, eğitim günü ve saati belirlendi.

Eğitim için belirlenen gün ve saatte en fazla 5 kişiden oluşan küçük gruplar şeklinde anneler, eğitim için hazırlanmış odaya alındı. Eğitim konuları (preterm bebeğin özellikleri, sorunları, taburculuğu, aşıları, izlemi, ev ortamında bakımı) annelere her gün bir oturum olacak şekilde toplam üç oturum şeklinde verildi. Her bir oturumda konular 45 dakikalık sürede ve 10 dakika ara verilerek yaklaşı iki saatte tamamland. Eğitim annelere düz anlatım, sorucevap, demonstrasyon gibi yöntemler kullanılarak ve araştırmacı tarafindan hazırlanan video izletilerek verildi. Eğitim sonunda annelere hazırlanan eğitim kitapçığı dağıtıldı. Eğitim içeriği ve kitapçık, literatüre dayanılarak hazırlandı ve 6 uzman kişinin görüşüne sunuldu.

Annelere eğitim sonunda bebeğin bakımına ve beslenmesine yönelik uygulamalar (kucağa alma, emzirme /biberonla besleme, genital bölge bakımı, bezini ve kıyafetlerini giydirme vb.) yaptırılarak, eksik oldukları konularda rehberlik edildi. Kontrol grubundaki annelere de servisin rutin eğitimi hemşireler tarafindan yapildı.

Bebek taburcu olduktan sonra, her iki gruptaki annelerle telefon görüşmeleri yapılarak ev ziyaretleri için uygun günler belirlendi. Her iki gruptaki bebeklere düzeltilmiş yaşına göre 1 . ayını doldurduğunda ilk ev ziyareti yapılarak annelere SÇBDF dolduruldu ve bebeğin fiziksel büyümesini değerlendirmek amacı ile ölçümler (vücut ağırlığı, boy uzunluğu, baş çevresi) araştırmacının yanında götürdüğü araçlar ile alındı ve Preterm Bebeğin İzlem Formuna kaydedildi. Bebekler, düzeltilmiş yaşlarına göre 3,6 ve 9 aylik olduklarında ev ziyaretleri tekrarlandi. Dil bilişsel, ince motor, kaba motor, sosyal beceri-öz bakım ve genel gelişimi değerlendiren AGTE kullanıldı. Fiziksel ölçümler, bebeğe ait sorunlar ve takip edilmesi gereken özellikler Preterm bebeğin izlem formuna kaydedildi. Annelerin sorduklar1 sorular cevaplandi. Ev ziyareti yaklaşık üç saat sürdü. 


\section{Verilerin Değerlendirilmesi}

Araştırma verileri değerlendirilirken tanımlayıcı istatistiksel metodların (ortalama, standart sapma, frekans) yanısıra niceliksel verilerin karşılaştırılmasında normal dağılım gösteren parametreler için student $\mathrm{t}$ testi, parametreler arasındaki ilişkilerin incelenmesinde Pearson korelasyon testi yapildı.

\section{Bulgular}

Her iki gruptaki annelerin ve babaların çoğunlukla ilköğretim mezunu oldukları, annelerin çalışmadığı, babaların çalıştı̆̆ 1 , annelerin primipar oldukları, multipar annelerin bebeklerinde pretermlik öyküsünün olmadığı, sosyal güvencelerinin olduğu ve ailelerin

Tablo 1. Bebeklerin Düzeltilmiş Yaşa Göre Fiziksel Ölçümlerinin Ortalama Değerlerinin Karşılaştırılması $(\mathrm{N}=75)$

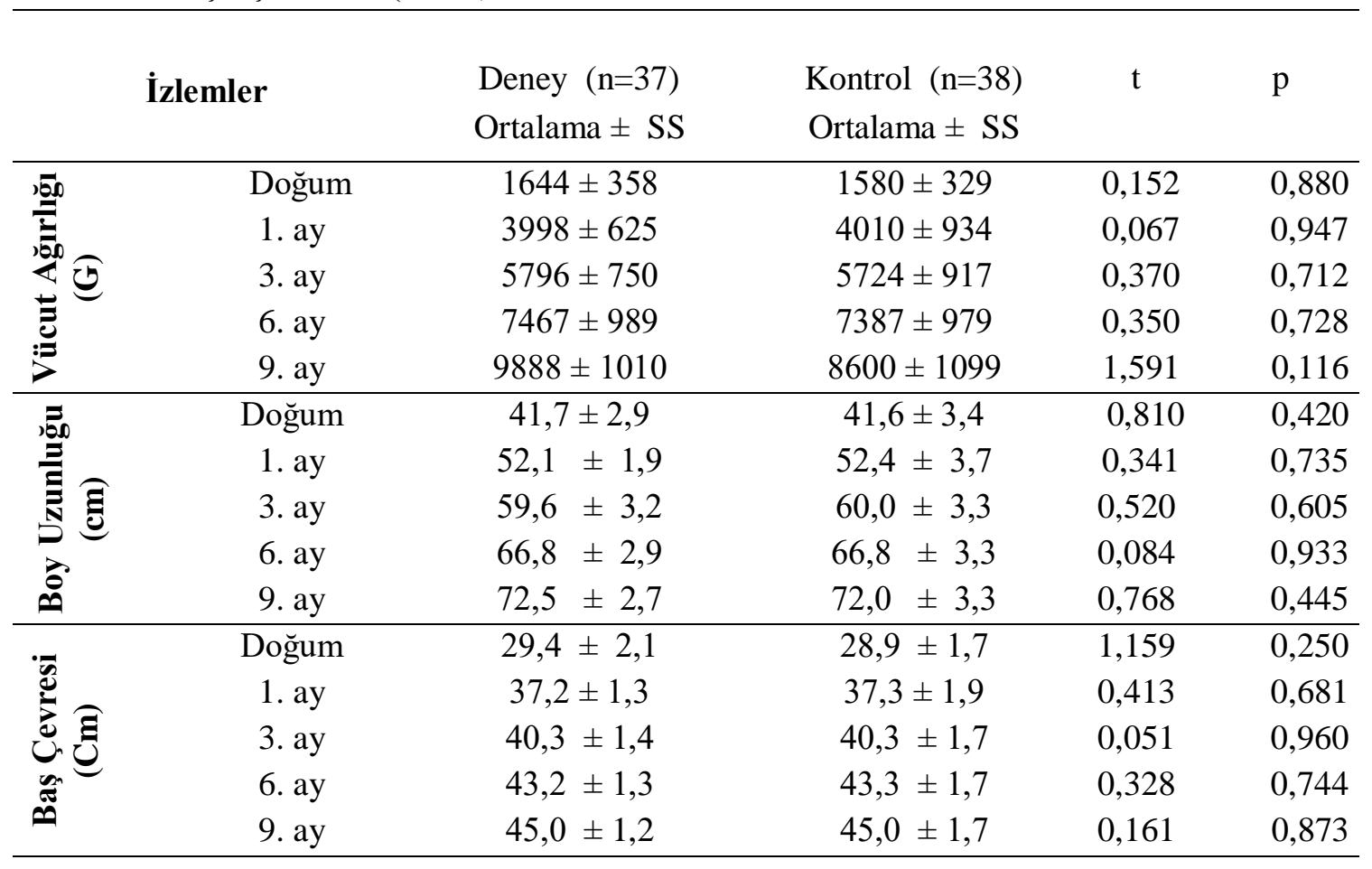

çekirdek aile tipinde olduğu görüldü. Tanıtıcı özellikler yönünden gruplar arasında fark görülmedi ( $>0.05)$. Bebeklerin anne sütü alma süresi deney grubu bebeklerde $6,6 \pm 3,9$ ay, kontrol grubu bebeklerde ise $4,7 \pm 4,2$ ay olup, gruplar anne sütü alma süreleri açısından karşılaştırıldığında aralarında deney grubu lehine anlamlı bir fark olduğu belirlendi $(\mathrm{p}<0.05)$.

Deney ve kontrol grubunu oluşturan preterm bebeklerin düzeltilmiş yaşa göre $1,3,6$ ve 9. aylardaki fiziksel ölçümlerinin (vücut ağırlığı, boy uzunluğu ve baş çevresi) ortalama değerleri arasında istatistiksel yönden anlamlı bir fark olmadığ $(\mathrm{p}>0.05)$ belirlendi (Tablo 1).

Deney ve kontrol grubu bebeklerin düzeltilmiş yaşa göre 3, 6 ve 9.aylardaki
AGTE'nin dil-bilişsel, ince motor, kaba motor, sosyal beceri-özbakım alt ölçek puan ortalamaları arasında deney grubu lehine anlamlı fark olduğu belirlendi $(\mathrm{p}<0.01)$. Benzer şekilde genel gelişim ve toplam puan ortalamaları arasında da deney grubu lehine anlamlı fark bulundu ( $\mathrm{p}<0.01)$ (Tablo 2).

Annelerin SÇBDF ölçeği alt boyutlarından aldıkları puan ortalamaları karşılaştırıldığında; deney grubundaki annelerin kontrol grubuna göre anlamlı derecede yüksek puan aldığı belirlendi (Tablo 3 ).

Deney ve kontrol grubundaki annelerin sorun çözme beceri puanları ile bebeklerinin genel gelişim puanları arasındaki korelasyonu Grafik 1 ve Grafik 2'de verilmiştir. 
Tablo 2. Bebeklerin AGTE’ye Göre Mental-Motor Gelişim Puan Ortalamalarının Karşılaştırılması (N=75)

\begin{tabular}{|c|c|c|c|c|c|}
\hline $\begin{array}{l}\text { Mental-Motor } \\
\text { Gelişim Alanları }\end{array}$ & $\begin{array}{c}\text { Düzeltilmiş } \\
\text { Yaş }\end{array}$ & $\begin{array}{l}\text { Deney }(n=37) \\
\text { Ortalama } \pm S S\end{array}$ & $\begin{array}{l}\text { Kontrol }(n=38) \\
\text { Ortalama } \pm \text { SS }\end{array}$ & $\begin{array}{c}\text { İstatistiksel } \\
\text { Analiz }\end{array}$ & $\mathrm{p}$ \\
\hline \multirow{3}{*}{$\begin{array}{l}\text { Dil Bilişsel } \\
\text { Gelişim }\end{array}$} & 3. ay & $6,5 \pm 0,9$ & $5,2 \pm 1,4$ & $\mathrm{z}=4,585$ & 0,001 \\
\hline & 6. ay & $12,8 \pm 1,7$ & $10,8 \pm 1,9$ & $\mathrm{t}=4,624$ & 0,001 \\
\hline & 9. ay & $16,8 \pm 1,3$ & $14,3 \pm 1,7$ & $\mathrm{z}=4,585$ & 0,001 \\
\hline \multirow{3}{*}{ İnce Motor Gelişim } & 3. ay & $2,3 \pm 0,5$ & $2,2 \pm 0,5$ & $\mathrm{z}=0,809$ & 0,418 \\
\hline & 6. ay & $11,3 \pm 1,0$ & $9,9 \pm 1,9$ & $\mathrm{z}=3,489$ & 0,001 \\
\hline & 9. ay & $12,9 \pm 0,2$ & $12,7 \pm 0,6$ & $\mathrm{z}=2,758$ & 0,006 \\
\hline \multirow{3}{*}{ Kaba Motor Gelişim } & 3. ay & $2,9 \pm 0,2$ & $2,8 \pm 0,5$ & $\mathrm{z}=1,466$ & 0,143 \\
\hline & 6. ay & $7,1 \pm 1,2$ & $6,5 \pm 1,3$ & $\mathrm{z}=1,846$ & 0,065 \\
\hline & 9. ay & $11,8 \pm 1,4$ & $10,8 \pm 1,8$ & $\mathrm{z}=2,534$ & 0,011 \\
\hline \multirow{3}{*}{ Sosyal Beceri-Özbakım } & 3. ay & $4,8 \pm 0,7$ & $4,3 \pm 1,0$ & $\mathrm{z}=1,958$ & 0,050 \\
\hline & 6. ay & $11,4 \pm 1,1$ & $9,4 \pm 2,0$ & $z=4,593$ & 0,001 \\
\hline & 9. ay & $15,5 \pm 1,3$ & $13,1 \pm 1,4$ & $\mathrm{z}=5,841$ & 0,001 \\
\hline \multirow{3}{*}{ Genel Gelişim } & 3. ay & $16,4 \pm 1,6$ & $14,5 \pm 2,4$ & $\mathrm{t}=4,096$ & 0,001 \\
\hline & 6. ay & $42,5 \pm 4,2$ & $36,6 \pm 5,5$ & $\mathrm{t}=5,230$ & 0,001 \\
\hline & 9. ay & $57,0 \pm 2,9$ & $50,8 \pm 3,6$ & $\mathrm{t}=8,140$ & 0,001 \\
\hline \multirow{3}{*}{ Toplam Puan } & 3. ay & $50,8 \pm 3,2$ & $47,0 \pm 4,6$ & $\mathrm{z}=3,976$ & 0,001 \\
\hline & 6. ay & $55,2 \pm 4,9$ & $48,4 \pm 6,4$ & $\mathrm{z}=5,225$ & 0,001 \\
\hline & 9. ay & $58,0 \pm 4,7$ & $47,5 \pm 6,7$ & $\mathrm{z}=4,585$ & 0,001 \\
\hline
\end{tabular}

* $t=$ Student $t$ test $; * * Z=$ Mann Whitney U test

Tablo 3- Annelerin SÇBDF Ölçeğinden Aldıkları Alt Boyut Puan Ortalamalarının Karşılaştırılması (N=63)

\begin{tabular}{|c|c|c|c|c|c|}
\hline Ölçek & $\begin{array}{l}\text { Dağılım } \\
\text { aralığı }\end{array}$ & $\begin{array}{c}\text { Annelerin Ölçek } \\
\text { Deney }(n=31) \\
\text { Ortalama } \pm \text { SS }\end{array}$ & $\begin{array}{c}\text { Ian Ortalamaları } \\
\text { Kontrol }(n=32) \\
\text { Ortalama } \pm \text { SS }\end{array}$ & $\mathrm{t}$ & $\mathrm{p}$ \\
\hline Çocuk Bakım Becerisi & $(1-9)$ & $7,8 \pm 0,9$ & $6,1 \pm 1,1$ & 6,655 & $0,001 * *$ \\
\hline Tarama & $(3-27)$ & $23,6 \pm 2,3$ & $21,9 \pm 3,6$ & 2,220 & $0,031 *$ \\
\hline Formülasyon & $(6-54)$ & $44,5 \pm 4,6$ & $37,9 \pm 6,7$ & 4,569 & $0,001 * *$ \\
\hline Ön değerlendirme & $(2-18)$ & $14,5 \pm 1,7$ & $11,5 \pm 2,2$ & 6,150 & $0,001 * *$ \\
\hline Planlama & $(6-54)$ & $46,2 \pm 4,3$ & $38,2 \pm 5,7$ & 6,330 & $0,001 * *$ \\
\hline Uygulama & $(3-27)$ & $24,2 \pm 3,0$ & $19,9 \pm 3,8$ & 4,939 & $0,001 * *$ \\
\hline Değerlendirme & $(4-36)$ & $31,1 \pm 2,8$ & $25,8 \pm 3,9$ & 6,293 & $0,001 * *$ \\
\hline Sorun Çözme Süreci & $(24-216)$ & $184,1 \pm 17,4$ & $155,2 \pm 22,0$ & 5,769 & $0,001 * *$ \\
\hline
\end{tabular}




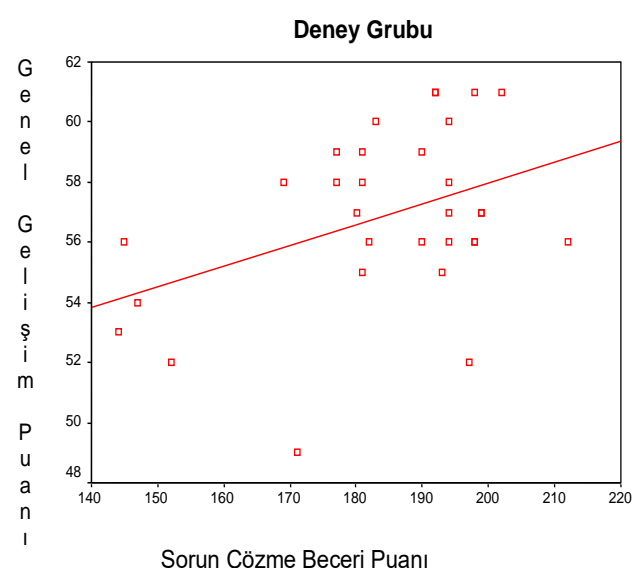

Grafik 1. Deney Grubundaki Annelerin Sorun Çözme Beceri Puanları İle Bebeklerinin Genel Gelişim Puanları Arasındaki Korelasyon

Deney grubundaki annelerin sorun çözme beceri puanları ile bebeklerinin genel gelişim puanları arasında pozitif yönde, orta düzeyde ve istatistiksel olarak anlamlı bir ilişki olduğu $(\mathrm{r}=0,41 ; \mathrm{p}=0,02$ (Grafik 1), başka bir deyişle annelerin sorun çözme beceri puanlarının arttıkça, bebeklerin genel gelişim puanlarının da arttığı belirlendi. Kontrol grubundaki annelerin sorun çözme beceri puanları ile bebeklerinin genel gelişim puanları arasında pozitif yönde, orta düzeyde bir ilişki bulunmuştur. Ancak bu ilişki istatistiksel olarak anlamlı değildi $(r=0,34$; $\mathrm{p}=0,59)($ Grafik 2).

\section{Tartışma}

Eve geçiş sürecinde; ebeveynlerin evdeki bakıma hazırlanması ve ev ortamında desteklenerek bakım hizmetlerinin verilmesi ile yenidoğanın sağllğ 1 korunabilir ve geliştirilebilir. ${ }^{10} \mathrm{Bu}$ yüzden preterm bebekler ve aileleri, sadece hastanede kaldıkları süre içinde değil hastaneden ayrıldıktan sonra da hemşireler ve diğer sağlık profesyonelleri tarafindan ev ziyaretleri ve telefon görüşmeleri ile sürekli desteklenmelidir. ${ }^{5,16}$ Halk sağllğı hemşireleri ve diğer ekip üyeleri tarafindan ev ziyaretleri yapılarak yaşadıkları güçlükler, endişeler ve ihtiyaçları sorgulanmalıdır. Ev ziyaretleri, ziyaretçi hemşire ve aile arasındaki güven ilișkisinin gelișmesine ve ailenin ihtiyaçlarına odaklanmayı sağlar. ${ }^{9}$ Amerikan Pediatri Akademisi (AAP), ev ziyareti programlarının anne ve bebek sağlığı açısından gerek prenatal ve postnatal, gerekse uzun süreli olumlu etkileri olduğunu belirtmektedir. Özellikle yapılan ev ziyaretlerinin; çocuk ihmali ve istismarını azalttığı, anne-bebek arasındaki etkileşimi geliştirdiği, annenin ebeveynliğe

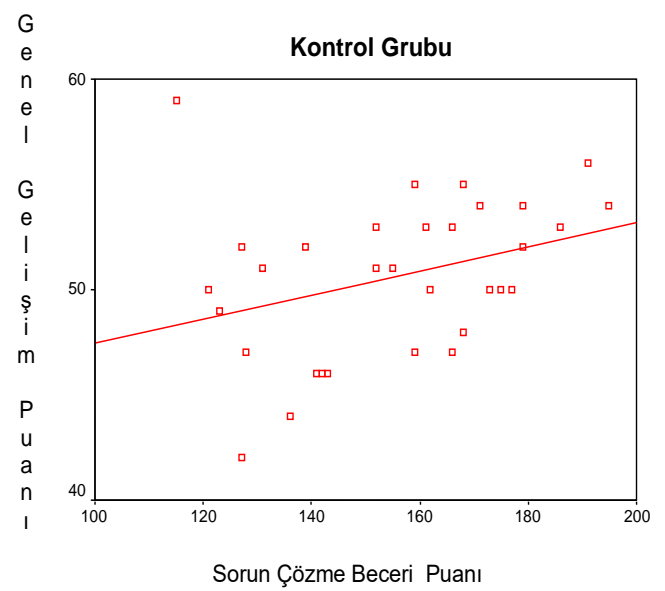

Grafik 2. Kontrol Grubundaki Annelerin Sorun Çözme Beceri Puanları İle Bebeklerinin Genel Gelişim Puanları Arasındaki Korelasyon

uyumunu kolaylaştırdığı, düşük doğum tartılı bebeklerde büyümeyi hızlandırdığg $1,{ }^{17}$ bebeklerin sağlığı ve gelişimleri üzerinde olumlu etkileri olduğu, annelerin beceri düzeylerinde artmaya neden olduğu belirtilmektedir. ${ }^{5,17}$

Araştırmada, deney ve kontrol grubunu oluşturan preterm bebeklerin düzeltilmiş yaşa göre $1,3,6$ ve 9. aylardaki fiziksel ölçümleri arasında anlamlı bir fark olmadığı belirlendi. Ancak deney grubundaki bebeklerin özellikle 9. aydaki tartı artışı kontrol grubuna göre daha fazla idi. Farkın istatistiksel olarak anlamlı olmamasında, deney grubundaki bebeklerin anne sütü alma süresinin daha uzun olmasına karşın kontrol grubundaki bebeklerin de farklı zamanlarda anne sütü ile beslenmeleri olabilir. Son y1llarda anne sütüne verilen önem ve hastanelerde yapılan emzirme eğitimleri, kontrol grubundaki bebeklerin de anne sütü alımlarını ve sonuçta büyümelerini olumlu yönde etkilemiş olabilir. Ayrica kontrol grubundaki annelere de ev ziyaretlerinin yapılması ve ev ziyaretleri sırasında bebekler adına yapılan yanlış uygulamalara etik olmadığ 1 için müdahale edilmesi ve gerektiğinde annenin sorduğu soruların yanıtlanması etken olmuş olabilir.

Preterm bebeklerin, baş çevresi için 1,5 yaş, vücut ağırlığı için 2 yaş, boy uzunluğu için ise 3,5 yaşında büyümeyi yakaladıkları belirtilmektedir. ${ }^{18}$ Araştırmada, her iki gruptaki bebeklerin öncelikle baş çevresi ve boy uzaması açısından term bebekleri yakaladıkları, vücut ağırlığında ise deney grubundaki bebeklerin bu farkı öncelikle yakaladıkları görülmüştür. Sonuçta, araştırma grubunda büyümeyi yakalama literatüre göre daha erken dönemde olmuştur. Ancak fiziksel ölçümler açısından deney grubu 
lehine istatistiksel fark saptanmamış ve Hipotez 1 kanıtlanamamıştır.

Araştırmada deney grubundaki bebeklerin genel gelişim puanlarının kontrol grubuna göre daha yüksek olduğu belirlendi (Tablo 2). Kaynaklarda preterm bebeği olan ebeveynlere yönelik eğitim programlarının uygulanmasının, ailenin bakıma katılmasının, ${ }^{9}$ annelerin bebekleri ile kurdukları pozitif ilişkinin, annenin bebeğe gösterdiği ilgi ve duyarlılığın, bebeklerine nasıl davranacaklarını bilmelerinin çocuğun gelişimini olumlu yönde etkilediği belirtilmektedir. ${ }^{19-22}$ Zahr (2000), 1-24 ay aras1 bebeklere yönelik yapılan ev ziyaretinin, bebeğin motor ve mental gelişim skorları üzerine olumlu etkisi olduğunu belirtmiştir. ${ }^{23}$ Araştırmanın sonuçları da, annelere yapılan eğitim ve ev ziyaretlerinin preterm bebeğin gelişimi üzerinde olumlu etkisi olduğu görüşünü ve Hipotez 2'yi desteklemektedir. Araştırmada "çocuk/bebek bakım becerisi" ve "sorun çözme becerisi" puan ortalamaları, deney grubu lehine anlamlı düzeyde farklı idi (Tablo 3).

Annenin problem çözme becerisi arttıkça kendine duyduğu güvenin de $\operatorname{arttığ1}$ belirtilmektedir. ${ }^{24}$ Kendine güvenmeyen veya kendini yeterli bulmayan ebeveynlerin evde bebeğin bakımı konusunda bağımsız kararlar almada güçlük yaşadıkları ve problem çözme becerilerinde yetersizlik gösterdikleri, kendilerini başarılı hissetmenin ise problem çözme becerisi üzerine olumlu etkisi olduğu bildirilmektedir. ${ }^{7}$ Yapılan çalışmalarda annelere, kendileri ve bebekleri ile ilgili hemşireler tarafından yapılan eğitimin ve desteğin; annelerin bakım becerilerini ve sorun çözme becerilerini olumlu etkilediği, bilgi düzeyi ile sorun çözme beceri düzeyleri arasında anlamlı bir ilişki olduğu, ${ }^{7,25}$ annelerin bebeklerine daha etkili bir şekilde bakım verdikleri ve başarılı bir şekilde ebeveynliğe uyum sağladıklarr, $1^{6,14,23,26}$ belirlenmiştir. Arslan'ın (2001) yaptığı çalışmada; planlı eğitim ve danışmanlık hizmeti verilen annelerin bilgi ve sorun çözme beceri düzeyinin verilmeyenlere göre önemli ölçüde arttığı ve bilgi düzeyi ile sorun çözme beceri düzeyleri arasında anlamlı bir ilişki olduğu bulunmuştur. ${ }^{27}$

Araştırmada, deney grubundaki annelerin sorun çözme beceri puanları arttıkça bebeklerinin de genel gelişim puanlarının arttığ 1 ve aralarında pozitif yönde, anlamlı bir ilişki olduğu belirlenmiş olup (Grafik 1 ve Grafik 2), sonuçlar Hipotez 3'ü desteklemektedir. Benzer şekilde yapılan diğer araştırmalarda da, ev ortamının ve ebeveynlerin beceri düzeylerinin, ${ }^{13}$ sağlanan desteğin ${ }^{9}$ bebeğin gelişimi üzerine olumlu katkı sağladığ 1 belirtilmektedir.

Pridham ve ark. (1994), sağlıklı term bebeği olan annelerin doğum sonrası ilk 3 aylık süre içinde hemşire ve hekimlerden yardım isteme ve yardım kullanma durumlarını inceledikleri çalışmalarında, annelerin özellikle ilk aylarda problem çözme konusunda yardım kaynağı olarak hemşireyi tanımladıklarını saptamışlardır. $\mathrm{Bu}$ sonuçlar, hemşireler tarafindan annelere verilen planlı eğitim programlarının ve evde izlemlerin annelerin bakım becerisi ve sorun çözme becerisinin gelişimine katkı sağladığını düşündürmektedir. ${ }^{24}$

Sonuç olarak; Preterm bebeği olan annelere yönelik hastanede yapılan planlı eğitimin ve ev ortamında sağlanan desteğin bebeklerin gelişimleri ve annelerin sorun çözme becerileri üzerinde etkili olduğu, ancak bebeklerin fiziksel büyümesi üzerinde etkili olmadığı belirlenmiştir.

Preterm bebeği olan annelere taburcu olmadan önce planlı taburculuk eğitimlerin yapılması, yazılı ve görsel materyallerin verilmesi, bebek ve annelerin ev ortamında hemşire tarafından izlenmesi önerilebilir.

\section{Sinırlılıkları}

- Kontrol grubu hastane ortaminda izlenemediği için bu gruba da ev ziyareti yapıld1. Ev ortamında ailelerin gereksinim duyduğu konularda sordukları sorulara, görülen yanlış uygulamalara ve belirlenen sorunlara etik olmadığı için müdahale edildi. Örneğin; araştırma sırasında kontrol grubundaki bir bebeğin annesi tarafindan istismar edildiği ve hırpalandığı, bir bebekte ise kalça çıkığı olduğu belirlendi. Her iki aile de, gerekli kurumlara yönlendirildi. Bebeğini istismar eden anneye ilaç tedavisi başland, kalça çıkı ̆̆1 olan bebeğe ise konservatif tedavi yöntemleri uyguland.

- Annelerin bebekleri taburcu olmadan önce yapacakları uygulamalar arasinda yer alan "bebek banyosu" hastane ortaminin uygun olmaması nedeniyle gerçekleştirilemedi. Bu nedenle bebek banyosu, anneye resimlerle anlatılarak gösterildi. Ziyaretler sirasında banyo konusunda destek isteyen annelere, ev ortamında anne ile birlikte banyo yaptırılarak bu uygulama annelere öğretildi. 


\section{Teșekkür}

Araştırmanın her aşamasında bilgi ve deneyimlerini paylaşan, değerli katkılarıyla rehberlik eden sayın Prof. Dr. Sevim SAVAŞER'e ve sayın Prof. Dr. Zeynep INCE'ye teşekkür ederiz.

\section{Kaynaklar}

1. Preterm birth. World Health Organization (WHO). [updated 2016 Nov ; cited 2017 June 20].Available from:

http://www.who.int/mediacentre/factshe ets/fs363/en/

2. Mancini A, While A. Discharge planning from a neonatal unit: An exploratory study of parents' views. Journal of Neonatal Nursing 2001; 7 (2): 59-62.

3. Turan MT, Bolışık B. Prematüre bebeği olan ailelere serviste uygulanan planlı eğitimin anne ve bebek üzerine olan etkilerinin incelenmesi. [An Investigation of the Effects of Planned Education Given in Clinic on Mothers and the Premature Babies]. Cumhuriyet Üniversitesi Hemşirelik Yüksekokulu Dergisi [Cumhuriyet University School of Nursing Journal] 2003; 7 (1):39-46.

4. Boykova M,Kenner C. Transition from hospital to home for parents of preterm infants. The Journal of Perinatal \& Neonatal Nursing 2012; 26 (1):81-87.

5. White-Traut $R$, Norr KF, Fabiyi $C$, Rankin KM, Li Z, Liu L. Mother-infant interaction improves with a developmental intervention for motherpreterm infant dyads. Infant Behav Dev.2013; 36(4): 694-706.

6. Yazıcı S. Annelerin öz-bakım gücü, sağlıklı bebeklerinin bakım sorunlarını çözme becerileri ve bu süreçte hemşirenin eğitici rolünün etkisi. [The self-care power of mothers, the ability to solve the care problems of healthy babies, and the influence of the educational role of the nurse in this process] [Doktora Tezi]. İstanbul Üniversitesi Sağlık Bilimleri Enstitüsü [Institute of Medical Sciences, Istanbul University], İstanbul, Türkiye,1995.

7. Tarkka MT. Guidance on breastfeeding by public health nurses has an impact on competence of first-time mothers.
Primary Health Care Research and Development 2001;2 (2): 80-87.

8. Yıldız S. Yüksek riskli yenidoğanların taburculuğa hazırlanmas1 ve preterm bebeklerin izlemi. [Preparation of high risk newborns for discharge and monitoring of preterm infants]. Dağoğlu T, Görak G, editör. Temel Neonatoloji ve Hemşirelik İlkeleri. İstanbul: Nobel Matbaac1l1k; 2002.p. 759-773.

9. Broedsgard A, Wagner L. How to facilitate parents and their premature infant for the transition home. International Nursing Review. 2005; 52(3):196-203.

10. Erdemir F. Medikal ve sosyal olarak yüksek riskli yenidoğanların taburculuğu: multidisipliner değerlendirme ve planlama. [Discharge of medical and socially high-risk neonates: multidisciplinary evaluation and planning]. 13.Ulusal Neonatoloji Kongresi ve Yenidoğan Hemşireliği Kongresi Kitabı. Kayseri; 2005.

11. Ovalı F. Prematüre bebeklerin takibi. [Follow-up of premature babies]. Dağoğlu T, editör. Neonatoloji. İstanbul: Alemdar Ofset; 2008. p.171-177.

12. İşler A. Prematüre bebeği olan annelerde olumlu anne bebek ilişkisinin başlatılmasında hemşirelik yaklaşımının önemi. [The importance of nursing approach in the initiation of a positive mother-infant relationship in mothers with premature babies]. [Yüksek Lisans Tezi]. İstanbul Üniversitesi Sağllk Bilimleri Enstitüsü [Institute of Medical Sciences, Istanbul University ], İstanbul, Türkiye, 2001.

13. Ritchie S. Primary Care of the Premature infant discharged from the neonatal intensive care unit. The American Journal of Maternal/Child Nursing 2002; 27(2) :76-85.

14. Chen YJ, Tseng YF, Hsu YY, Lin YF, Tseng YY, Chien CH. Effectiveness of videotape education for mothers of prematurity. Kaohsiung J Med Sci.1998; 14 (12): 800-806.

15. Savaşır I, Sezgin N, Erol N. Ankara Gelişim Tarama Envanteri. [Ankara Development Screening Inventory] Ankara: Rekmay Ltd.Şti.;1998

16. Merritt TA, Pillers D, Prows SL. Early NICU discharge of very low birth weight 
infants: a critical review and analysis. Seminars in Neonatology 2003;8(2) : 95 115.

17. American Academy of Pediatrics (AAP). Committee on Fetus and Newborn. Hospital discharge of the high-risk neonate-proposed guidelines. Pediatrics 1998; 102 (2): 411-417.

18. İnce Z. Hastane dış1 preterm izlenmesi [Non-hospital preterm monitoring]. Çocuk Dergisi [The Journal of the Child] 2001; 1 :181-184.

19. Holditch-Davis D, Miles MS, Belyea M. Feeding and nonfeeding interactions of mothers and prematures. Western Journal of Nursing Research 2000; 32 (3): 320-334.

20. Sola C, Diken İH. Gelişimsel gerilik riski altındaki prematüre ve düşük doğum ağırlıklı çocuğa sahip annelerin gereksinimlerinin belirlenmesi. [Determine the needs of mothers who have at-risk infants and toddlers with premature/low birth weight for development delays]. Ankara Üniversitesi Ĕgitim Bilimleri Fakültesi Özel Eğitim Dergisi [Ankara University Faculty of Educational Sciences Special Education Journal] 2008; 9 (2): 21-36.

21. Cusson RM. Factors influencing language development in preterm infants.

Journal of Obstetrics, Gynecology \& Neonatal Nursing 2002; 32 (3): 402 -409

22. Keilty B, Freund M. Caregiver-child interaction in infants and toddlers born extremely premature. Journal of Pediatric Nursing 2005; 20(3): 181-189.

23. Zahr L K. The relationship between maternal confidence and mother-infant behaviors in premature infants. Res Nurs Health. 1991; 14 (4) : 279-286.

24. Pridham FK, Chang A, Chiu Y. Influences on mothers' use of clinician help in the infants's first three months. Public Health Nursing 1994; 11 (2) : 8089.

25. Uçar Ö, Bayık A. Yeni doğum yapmış annelerin taburculuk sirasinda fonksiyonel statülerinin incelenmesi. [Examination of the functional status of new-born mothers during discharge]. VII.Ulusal Hemşirelik Kongresi Bildiri Özet Kitabı. Erzurum;1999.
26. Leahy WP. First-time mothers: social support and confidence in infant care. Journal of Advanced Nursing 2005; 50(5): 479-488.

27. Arslan F. Primipar annelere gebelikte ve doğum sonu bebek bakımı konusunda verilen danışmanlık ve eğitim hizmetinin yaşam kalitesi üzerine etkisinin belirlenmesi. [Primipar maternal counseling on gestation and postpartum baby care and determining the effect of education service on quality of life] [Doktora Tezi]. GATA Hemşirelik Yüksek Okulu, [GATA School of Nursing], Ankara, Türkiye,2001. 